J. Amer. Soc. Hort. ScI. 115(1):14-19. 1990.

\title{
Apple Thinning by Photosynthetic Inhibition
}

R.E. Byers ${ }^{1}$

Virginia Agricultural Experiment Station, Virginia Polytechnic Institute and State University, Winchester, VA 22601

\author{
J.A. Barden ${ }^{1}$ and R.F. Polomski ${ }^{2}$ \\ Department of Horticulture, Virginia Polytechnic Institute and State University, \\ Blacksburg, VA 24061 \\ R.W. Young ${ }^{3}$ \\ Department of Biochemistry, Virginia Polytechnic Institute and State University, \\ Blacksburg, VA 24061 \\ D.H. Carbaugh ${ }^{4}$ \\ Virginia Agricultural Experiment Station, Virqinia Polytechnic Institute and State University, \\ Winchester VA 22601
}

\begin{abstract}
Additional index words. terbacil, Malus domestics, herbicides, shading, photosynthesis
Abstract. Shading (92\%) of 'Redchief Delicious' apple (Malus domestics Borkh.) trees for 10-day periods from 10 to 20, 15 to 25, 20 to 30, and 25 to 35 days after full bloom (DAFB) caused greater fruit abscission than shading from 5 to 15,30 to 40,35 to 45 , or 47 to 57 DAFB. Fruit 8 to $33 \mathrm{~mm}$ in diameter (10 to 30 DAFB) were very sensitive to 10 days of shade, even though fruit sizes of 6 to $12 \mathrm{~mm}$ are considered the most sensitive to chemical thinners. In a second test, shading for 3 days caused fruit thinning; 5 days of shade in the periods 18 to 23,23 to 28 , and 28 to 33 DAFB caused greater thinning than 11 to 16 or 33 to 38 DAFB. Shading reduced photosynthesis (Pn) to about onethird that of noncovered trees. Terbacil $\left(50 \mathrm{mg} \cdot \mathrm{liter}^{-1}\right)+\mathrm{X}-77$ surfactant $\left(1250 \mathrm{mg} \cdot \mathrm{liter}^{-1}\right)$ applied with a handpump sprayer 5, 10, or 15 DAFB greatly reduced fruit set and caused some leaf yellowing, particularly in the earliest treatments. Terbacil reduced Pn by more than $90 \%$ at 72 hours after application. Shoot growth of trees defruited by shade or terbacil was equivalent to defruited or deblossomed trees; ethephon $\left(1500 \mathrm{mg} \cdot \mathrm{liter}^{-1}\right)$ inhibited tree growth and defruited trees. No terbacil residues were dectected in fruit at harvest from applications made 5, 15, 20, 25, or 30 DAFB. Eleven of 12 photosynthesis-inhibiting herbicides were also found to thin 'Redchief Delicious' apple trees. Shading caused more thinning than terbacil at the later applications, which may reflect poorer absorption and/or lesser photosynthetic inhibition than when terbacil was applied to older leaves.
\end{abstract}

Spur 'Delicious' strains of apple normally set heavy crops and are difficult to thin adequately with currently available thinning agents (Byers, 1978; Byers et al., 1982; Herrera-Aguirre and Unrath,, 1980; Unrath, 1978, 1981). High rates of naphthaleneacetic acid (NAA) or naphthaleneacetamide (NAD) may cause many dwarfed (pygmy) fruit (Byers, 1978; Byers et al., 1982; Rogers and Thompson, 1969; Rogers and Williams, 1977; Unrath 1978, 1981). Carbaryl plus lower rates of NAA (5 mg.liter $\left.{ }^{-1}\right)$ have given excellent results in some years, but have caused serious overthinning and/or pygmy fruit development in others (Byers, 1978; Byers et al., 1982; Rogers and Williams, 1977). Combinations of ethephon plus carbaryl have over- and underthinned in some tests (Byers et al., 1982; unpublished data), but thinned adequately in others (Herrera-Aguirre and Unrath, 1980; Unrath, 1978).

Shading of apple or peach limbs or spraying trees with chemical photosynthetic inhibitors can induce fruit abscission (Byers et al., 1984, 1985; DelValle et al., 1985) without pygmy fruit development in 'Delicious' (Byers et al., 1985). Terbacil, but not shading, has caused leaf injury in some experiments, par-

Received for publication 9 Feb. 1987. We thank Ciba-Geigy, Dupont, BASF, and Shell Chemical companies for supply of various photosynthetic inhibitors and Chevron Chemical for X-77 surfactant; Sharon Myers, Raymond Myers, and Philip Ramsey, Dept. of Statistics, VPI \& SU, for statistical assistance and analysis. The cost of publishing this paper was defrayed in part by the payment of page charges. Under postal regulations, this paper therefore must be hereby marked advertisement solely to indicate this fact.

'Professor of Horticulture.

${ }^{2}$ Graduate Research Assistant.

${ }^{3}$ Professor of Biochemistry.

${ }^{4}$ Agricultural Manager. titularly when applied dilute with a hand-pump sprayer (Byers et al., 1984, 1985; DelValle et al., 1985).

The objectives of these experiments were: 1) to explore several chemical classes of photosynthetic inhibitors for apple thinning activity and degree of leaf injury, 2) to determine the most sensitive period when photosynthetic inhibition would cause apple thinning, and 3) to determine the effect of terbacil or shading on photosynthetic activity of apple leaves at rates that cause thinning.

\section{Materials and Methods}

Several studies were conducted in 1985 and 1986 on 5- and 6-year-old 'Redchief Delicious'/MM.111 trees located near Winchester, Va. These trees set a heavy crop in the fourth season and required much hand-thinning. All experiments were laid out in randomized complete-block designs. Each treatment was applied to whole, single-tree plots within six replicate blocks, except where indicated. Blocks were consecutively oriented within tree rows. Spray treatments were applied with a 5-liter stainless steel hand-pump to the point of drip. Full bloom occurred 19 Apr. 1985 and 22 Apr. 1986.

Experiments 1, 2, and 3. Twelve photosynthesis-inhibiting chemicals used in these experiments are listed in Table 1. In 1985,11 of these inhibitors were applied to four trees each in a randomized block design (Expt. 1), but, because of rain, a second experiment (Expt. 2) was conducted to retest those materials that may not have had sufficient time to dry before the rain (propazine, dipropetryn, metribuzin, bentazon). In 1986, 12 inhibitors were applied as described above (Expt. 3), but rates were adjusted based on leaf injury and thinning responses 
observed in 1985 . The surfactant X-77 at $0.0125 \%$ (v/v) was added to all treatments in both years. When significant injury occurred in an experiment, injury was rated from 0 to $10(0=$ no injury, 4 = heavy interveinal yellowing, $5=$ interveinal necrotic leaves, $10=$ complete defoliation and twig injury or death).

Experiment 4. Black polypropylene shade material (92\% shade) (E.C. Geiger, Harleysville, Pa.) was used to enclose whole trees for 10-day periods in the intervals 5 to 15,10 to 20,15 to 25 , 20 to 30,25 to 35,30 to 40,35 to 45 , and 47 to 57 DAFB. The shade material measured $90 \%$ shade on an overcast day, but, when placed at an angle to the sun draped over the tree, 95\% shade was measured using a LI-COR Model LI-85 light meter with a quantum sensor (Lincoln, Neb.). Terbacil (50 $\mathrm{mg} \cdot$ liter $\left.^{-1}\right)+\mathrm{X}-77\left(2500 \mathrm{mg} \cdot\right.$ liter $\left.^{-1}\right)$, applied at 5, 10, 15, $20,25,30,35$, or $40 \mathrm{DAFB}$, was also compared to shade, carbaryl (900 mg.liter $\left.{ }^{-1}\right)+$ NAA $\left(10 \mathrm{mg} \cdot \mathrm{liter}^{-1}\right)+$ a nonphytotoxic, highly refined paraffinic, 70 -sec superior oil (2500 $\mathrm{mg} \cdot$ liter $\left.^{-1}\right)$, ethephon (1500 mg.liter ${ }^{-1}$ ), hand-defruited, handdeblossomed, and hand-thinned trees. At harvest, $2.5-\mathrm{kg}$ samples of fruit were collected from terbacil-sprayed trees 5, 15, 20, 25, or 30 DAFB and were analyzed for residues using standard liquid chromatographic methods described by Pease et al. (1978). Fruit per tree was counted between 30 and 61 DAFB and was expressed as fruit per square centimeter of trunk crosssectional area (TCSA). A 10-fruit sample was collected from each tree near harvest and sized with a band-type caliper. Fruit color was estimated as a percentage of fruit surface showing red and fruit firmness was determined with a Magness-Taylor penetrometer (D. Ballauf, Washington, D. C.) with an 1l-mmdiameter tip. Soluble solids concentration (SSC) was determined by use of a Labeco refractometer (Laboratory Equipment Co., San Francisco) from a composite juice sample from the 10 fruits noted.

The average shoot length of the five longest terminal shoots (four scaffolds plus central leader) on each tree was measured the following dormant season and expressed as a percentage of the control. Trunk circumference of each tree was measured 30 cm above the soil on 1 May 1985 and in Dec. 1985. The increment in diameter for the 1985 season was calculated and expressed as a percentage of that of the control. Return bloom was rated from 0 to $10(0=$ no bloom, $4=$ enough for full crop, $10=$ all spurs flowering).

A 5-kg sample of fruit was collected from trees treated with $50 \mathrm{mg} \cdot$ liter $^{-1}$ terbacil $+\mathrm{X}-7715 \mathrm{DAFB}$. Terbacil residue analysis of fruit collected at harvest was conducted according to Pease et al. (1978). Detection levels in fruit tissues were $0.01 \mathrm{mg} \cdot \mathrm{liter}^{-1}$, with a $67 \%$ recovery rate in controlled samples.

Experiment 5. Shade material (92\%) was used to enclose six whole trees for either $1,3,5$, or 7 days 13 to 14,12 to 15,11 to 16 , and 10 to $17 \mathrm{DAFB}$, respectively. In addition, shade material was used to enclose six trees for 5 days 18 to 23,23 to 28,28 to 33 , or 33 to 38 DAFB. Nonthinned and handthinned controls were also included for comparison. Fruit diameter, average shoot length, and trunk diameters were taken as in Expt. 4.

Experiment 6. Net photosynthesis (Pn) was measured in the field with a portable ADC (Analytical Development Co., supplied by P.K. Morgan Instruments, Andover, Mass.) LCA-2 infrared $\mathrm{CO}_{2}$ analyzer (LCA-2) equipped with a Parkinson leaf chamber (P.K. Morgan Instruments) that exposed $6.25 \mathrm{~cm}^{2}$ of leaf to sunlight. Only bright, cloudless days were chosen for Pn measurements, which were taken between 10:00 AM and 1:00 PM and consecutively by block. Photosynthesis of three leaves on each of two trees treated with terbacil $0,2,24,72$, or 120 hr previously were measured at 20 DAFB.

Experiment 7. Photosynthesis of trees that were shaded with polypropylene shadecloth 5 to 15 or 10 to 20 DAFB and of nonshaded trees was measured with shade either on or off the trees at 20 DAFB (three leaves on each of two trees for each treatment).

All data were averaged for each single-tree replicate before performing LSD $(0=0.05)$, Duncan's multiple range procedure (0.05), or regression analysis. General Linear Model (GLM) procedures of the Statistical Analysis System (SAS) program package (SAS Institute, 1982) were used for analysis of variance.

Table 1. Photosynthetic inhibitors of various classes tested for thinning apple fruits.

\begin{tabular}{|c|c|c|c|c|}
\hline Chemical class & Trade Name & Common name & Chemical name & Source \\
\hline \multirow[t]{3}{*}{ Substituted ureas } & Tenoran & Chloroxuron & 3-[p-(p-Chlorophenoxy)phenyl $]-1,1$-dimethylurea & Ciba-Geigy \\
\hline & Cotoran & Fluometuron & 1,1-Dimethyl-3-( $\alpha, \alpha, \alpha$-trifluoro-m-tolyl)urea & Ciba-Geigy \\
\hline & Bladex & Cyanazine & $\begin{array}{l}\text { 2-[[4-Chloro-6-(ethylamino)-s-triazine-2-yl]amino]- } \\
\text { 2-methyl proprionitrile }\end{array}$ & Shell Development \\
\hline Uracils & Sinbar & Terbacil & 3-tert-butyl-s-chloro-6-methyluracil & DuPont \\
\hline \multicolumn{5}{|l|}{ Substituted Trazines } \\
\hline \multirow[t]{2}{*}{ Chloroazine } & Princep & Simazine & 2-Chloro-4,6-bis(ethylamino)-s-triazine & Ciba-Geigy \\
\hline & Milogard & Propazine & 2-Chloro-4,6-bis(isopropylamino)-s-triazine & Ciba-Geigy \\
\hline \multirow[t]{2}{*}{ Meth-thio } & Caparol & Prometryn & 2,4-bis(isopropylamino)-6-(methylthio)-s-triazine & Ciba-Geigy \\
\hline & Igram & Terbutryn & $\begin{array}{l}\text { 2-(tert-butylamino)-4-(ethylamino)-6-(methyl- } \\
\text { thio)-s-triazine }\end{array}$ & Ciba-Geigy \\
\hline Ethylthio & Sancap & Dipropetryn & 2-(Ethylthio)-4,6-bis(isopropylamino)-s-trazine & Ciba-Geigy \\
\hline Asymetrical & Sencor & Metribuzin & $\begin{array}{l}\text { 4-Amino-6-(1,1 dimethyl ethyl)-3-(methylthio- } \\
\text { 1,2,4-as-triazine-5-(4H)-one }\end{array}$ & DuPont \\
\hline Benzothiadiazol & Basagran & Bentazon & $\begin{array}{l}\text { 3-isopropyl-1 } H \text {-2,1,3-benzothiadiazin-4(3H)-one- } \\
\text { 2,2-dioxide }\end{array}$ & BASF \\
\hline Pyridazinon & Pyramin & Pyrazon & 5-Amino-4-chloro-2-phenyl-3(2H)-pyridazinone & BASF \\
\hline
\end{tabular}


Table 2. Effect of photosynthetic inhibitors on fruit thinning and leaf injury of 'Redchief Delicious' apples. ${ }^{\mathrm{z}}$

\begin{tabular}{|c|c|c|c|c|c|c|c|c|c|c|}
\hline \multirow[b]{3}{*}{ Inhibitor } & \multicolumn{4}{|c|}{$1985^{y}$} & \multicolumn{6}{|c|}{$1986^{y}$} \\
\hline & \multirow{2}{*}{$\begin{array}{c}\text { Concn }^{y, x} \\
\left(\mathrm{mg} \cdot \text { liter }^{-1}\right)\end{array}$} & \multicolumn{2}{|c|}{$\begin{array}{c}\text { Fruit } / \mathrm{cm}^{2} \\
\text { cross-sectional } \\
\text { area of trunk } \\
(\mathrm{FB}+59)\end{array}$} & \multirow{2}{*}{$\begin{array}{l}\text { Injury } \\
\text { rating } \\
(0-10) \\
\end{array}$} & \multirow{2}{*}{$\begin{array}{l}\text { Concn }{ }^{\mathrm{x}, \mathrm{w}} \\
\text { (mg.liter) }\end{array}$} & \multirow{2}{*}{$\begin{array}{c}\text { Fruit/cm }{ }^{2} \\
\text { cross-sectional } \\
\text { area of trunk }{ }^{\mathrm{v}} \\
(\mathrm{FB}+51) \\
\text { Expt. } 3\end{array}$} & \multirow{2}{*}{$\begin{array}{c}\text { Injury } \\
\text { rating } \\
(0-10) \\
(\mathrm{FB}+23)\end{array}$} & \multirow{2}{*}{$\begin{array}{c}\text { Injury } \\
\text { rating } \\
(0-10) \\
(\mathrm{FB}+34) \\
\end{array}$} & \multirow[t]{2}{*}{$\begin{array}{l}\text { Average } \\
\text { shoot } \\
\text { length } \\
\text { (\% of } \\
\text { control) }\end{array}$} & \multirow[t]{2}{*}{$\begin{array}{c}\text { Trunk } \\
\text { diameter } \\
\text { increment } \\
\text { (\% of } \\
\text { control) }\end{array}$} \\
\hline & & Expt. 1 & Expt. 2 & & & & & & & \\
\hline Control & -.- & $4.7 \mathrm{a}$ & $2.9 \mathrm{a}$ & --- & -.- & $6.0 \mathrm{a}$ & $0.0 \mathrm{a}$ & $0.0 \mathrm{a}$ & $100 \mathrm{abc}$ & $100 \mathrm{abc}$ \\
\hline Terbutryn & 200 & $2.4 \mathrm{bc}$ & -- & 2 & 100 & $1.0 \mathrm{ef}$ & $3.5 \mathrm{e}$ & $2.3 \mathrm{e}$ & $127 \mathrm{c}$ & $156 \mathrm{de}$ \\
\hline Terbacil & 50 & $2.0 \mathrm{c}$ & $-\cdots$ & 2 & 50 & $3.9 \mathrm{~b}$ & $1.8 \mathrm{bc}$ & $0.0 \mathrm{a}$ & $113 b c$ & 130 bcde \\
\hline Simazine & 50 & $5.1 \mathrm{a}$ & --- & 0 & 2000 & $3.6 \mathrm{bc}$ & $0.2 \mathrm{a}$ & $0.0 \mathrm{a}$ & $111 \mathrm{bc}$ & 134 bcde \\
\hline Prometryn & 50 & $3.0 \mathrm{bc}$ & -- & 2 & 100 & $1.6 \mathrm{def}$ & $2.3 \mathrm{~cd}$ & $2.3 \mathrm{e}$ & $127 \mathrm{c}$ & $181 \mathrm{e}$ \\
\hline Chloroxuron & 200 & $4.0 \mathrm{a}$ & -- & 0 & 2000 & $2.1 \mathrm{de}$ & $1.2 \mathrm{~b}$ & $1.2 \mathrm{bc}$ & $115 \mathrm{bc}$ & $120 \mathrm{bcd}$ \\
\hline Fluometuron & 50 & $2.5 \mathrm{bc}$ & -- & 0 & 100 & $2.1 \mathrm{de}$ & $2.8 \mathrm{de}$ & $0.0 \mathrm{a}$ & $122 \mathrm{c}$ & 157 de \\
\hline Propazine & 200 & $3.9 \mathrm{ab}$ & $2.5 \mathrm{ab}$ & 0 & 2000 & $2.2 \mathrm{de}$ & $0.3 \mathrm{a}$ & $1.0 \mathrm{~b}$ & $100 \mathrm{abc}$ & 151 cde \\
\hline Dipropetryn & 100 & $4.0 \mathrm{ab}$ & $1.4 \mathrm{bc}$ & 0 & 4000 & $0.4 \mathrm{f}$ & $2.7 \mathrm{~d}$ & $4.3 \mathrm{f}$ & $112 b c$ & 132 bcde \\
\hline Metribuzin & 100 & $2.3 \mathrm{bc}$ & $0.7 \mathrm{c}$ & 0 & 200 & $2.3 \mathrm{de}$ & $2.8 \mathrm{de}$ & $0.0 \mathrm{a}$ & $128 \mathrm{c}$ & $172 \mathrm{de}$ \\
\hline Bantazon & 200 & $5.3 \mathrm{a}$ & $1.6 \mathrm{c}$ & 0 & 400 & $2.5 \mathrm{~cd}$ & $2.8 \mathrm{de}$ & $1.3 \mathrm{~cd}$ & $121 \mathrm{c}$ & 163 de \\
\hline Cyanazine & 50 & $2.6 \mathrm{bc}$ & $-\cdots$ & 0 & 100 & $2.6 \mathrm{~cd}$ & $3.0 \mathrm{de}$ & $1.6 \mathrm{~d}$ & $115 \mathrm{bc}$ & 133 bcde \\
\hline Pyrazon & --- & & & & 200 & $5.9 \mathrm{a}$ & $0.3 \mathrm{a}$ & $0.0 \mathrm{a}$ & $79 \mathrm{a}$ & $63 \mathrm{a}$ \\
\hline Hand-thinned & --- & & & & --- & $2.8 \mathrm{bcd}$ & $0.0 \mathrm{a}$ & $0.0 \mathrm{a}$ & $121 \mathrm{c}$ & 141 bcde \\
\hline
\end{tabular}

${ }^{2}$ Mean separation within columns by Duncan's multiple range test $(P=0.05)$.

yFull bloom occurred 19 Apr. 1985 and 22 Apr. 1986.

$\mathrm{xX}-77$ at $0.0125 \%(\mathrm{v} / \mathrm{v})$ was added as a surfactant.

whole apple trees were sprayed with a hand-pump sprayer: Expt. 1, 2 May 1985 (FB + 13 days); Expt. 2, 6 May 1985 (FB

$+17)$; and Expt. 3, 7 May $1986(\mathrm{FB}+15)$. Fruit size at treatment was $6.5 \pm 0.23,12.5 \pm 0.47,8.8 \pm 0.41 \mathrm{~mm}$ for each experiment, respectively.

"Fruit counts were made 17 June 1985 (FB + 59 days) on apples and 12 June 1986 (FB + 51 days).

"Average shoot length for five terminals (four scaffolds plus central leader) was $38.9 \mathrm{~cm}$; mean trunk diameter increment for 1986 was $0.40 \mathrm{~cm}$.

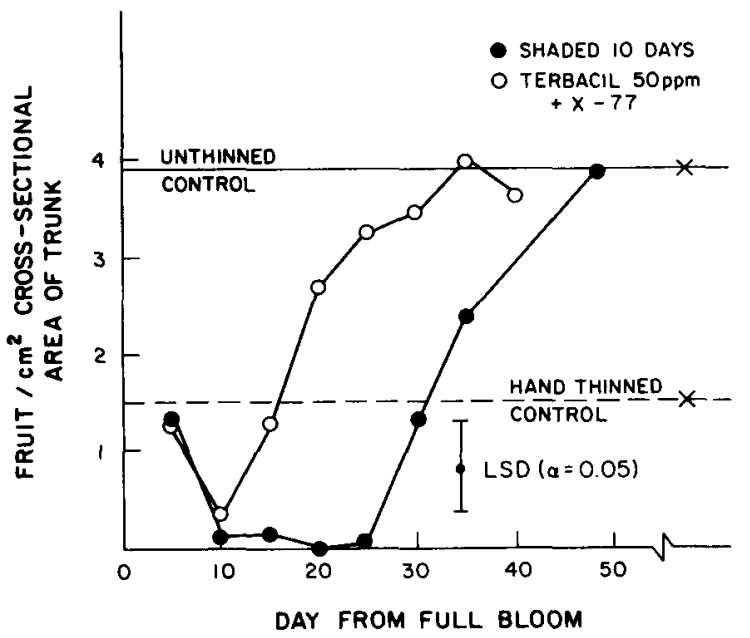

Fig. 1. Effect of terbacil sprays or shading of whole trees of 'Redchief Delicious' on fruit set. Each point represents six treated trees. Shaded trees were enclosed with $92 \%$ shade material for 10 days [the point was placed at the beginning date after full bloom (DAFB), i.e., at 5 days $=$ shade $(5$ to 15 days) $)$, sprayed with terbacil at 5 DAFB, hand-thinned, or unthinned controls. (Expt. 4, 1985). Vertical bar represents $\mathrm{LSD}, \mathrm{P}=0.05$.

\section{Results}

In 1985, terbutryn, terbacil, prometryn, fluometuron, metribuzin, bentazon, and cyanazine caused significant fruit thinning (Table 2, Expts. 1 and 2). In 1986, all of the inhibitors except pyrazon caused thinning (Table 2, Expt. 3). Propazine, sima- zine, terbacil, fluometuron, and metribuzin seemed to cause less injury than other materials for the degree of thinning achieved. Where fruit thinning occurred, both shoot length and trunk diameter increased in spite of injury.

Experiment 4. In 1985, shading 5 to 15 DAFB was not as effective in reducing fruit set as shading 10 to 20,15 to 25,20 to 30 , or 25 to 35 DAFB (Fig. 1). Shading trees 30 to 40 DAFB and later became progressively less effective in reducing fruit set and, by 47 to 57 DAFB, shading was completely ineffective.

Terbacil (50 mg.liter $\left.{ }^{-1}\right)+X-77\left(1250 \mathrm{mg} \cdot\right.$ liter $\left.^{-1}\right)$ also caused fruit abscission during the same periods as shading, but shade caused more fruit abscission and for later periods than this particular concentration of terbacil (Fig. 1). Where crop loads were greatly reduced (terbacil at 10 DAFB), fruit size was increased, but, in general, shading or terbacil did not influence fruit size at harvest (Table 3). Since control trees were not excessively loaded with fruit, fruit size and the differences in tree growth between controls and thinned treatments were not as large as expected, although hand-thinning caused a significant increase in fruit size. Carbaryl + NAA +70 -sec oil did not defruit trees, but ethephon almost did. Ethephon-treated trees had fruit that were much smaller than expected, since their crop load was much lower than the hand-thinned treatment and fruit size of the hand-thinned trees was larger than the ethephon-treated trees. Furthermore, fruit size of the $50 \mathrm{mg} \cdot \mathrm{liter}^{-1}$ terbacil (10 DAFB) treatment was much larger than ethephon-treated fruit, although both treatments had similar crop loads. Average terminal shoot length was greatly reduced by ethephon $\left(1500 \mathrm{mg}^{\circ} \cdot \mathrm{liter}^{-1}\right)$, while return bloom was equivalent to defruited and deblossomed trees. Mean shoot length and TCSA of shaded and terbacil-treated trees were inversely related to crop load. Terminal shoot growth 
Table 3. Effect of shading, terbacil, and other growth regulators on 'Redchief Delicious' apple fruit set, fruit set, fruit size, and tree growth (Expt. 4, 1985).

\begin{tabular}{|c|c|c|c|c|c|c|c|}
\hline Treatment $^{\mathrm{z}}$ & $\begin{array}{c}\text { Concn } \\
\left(\mathrm{mg}-\text { liter }^{-1}\right) \\
\end{array}$ & $\begin{array}{l}\text { Timing } \\
(\mathrm{DAFB}) \\
\end{array}$ & $\begin{array}{c}\text { Fruit } / \mathrm{cm}^{2} \\
\text { cross-sectional } \\
\text { area of trunk } \\
(\mathrm{FB}+30)\end{array}$ & $\begin{array}{c}\text { Fruit } \\
\text { diameter } \\
(\mathrm{cm})\end{array}$ & $\begin{array}{c}\text { Average } \\
\text { shoot } \\
\text { length } \\
\text { (\% of control) }\end{array}$ & $\begin{array}{l}\text { Return } \\
\text { bloom }^{v} \\
(0-10) \\
\end{array}$ & $\begin{array}{l}\text { Trunk diameter } \\
\text { increment } \\
(1985)^{\mathrm{w}} \\
(\% \text { of control) }\end{array}$ \\
\hline Control & & --- & 3.90 & 7.42 & 100 & 2.8 & 100 \\
\hline Hand-thinned & & 41 & 1.51 & 7.98 & 122 & 4.3 & 114 \\
\hline \multirow[t]{8}{*}{ Shade $(92 \%)$} & & $5-15$ & 1.36 & 7.57 & 111 & 3.2 & 114 \\
\hline & & $10-20$ & 0.10 & --- & 122 & 3.2 & 118 \\
\hline & & $15-25$ & 0.16 & $\cdots$ & 122 & 4.5 & 133 \\
\hline & & $20-30$ & 0.00 & --- & 129 & 4.7 & 137 \\
\hline & & $25-35$ & 0.08 & -- & 129 & 5.3 & 138 \\
\hline & & $30-40$ & 1.29 & 7.54 & 116 & 4.0 & 106 \\
\hline & & $35-45$ & 2.41 & 7.44 & 87 & 2.5 & 82 \\
\hline & & $47-57$ & 3.86 & 7.57 & 89 & $\ldots$ & 79 \\
\hline \multirow[t]{10}{*}{ Terbacil } & 50 & 5 & 1.31 & 7.75 & 119 & 3.3 & 99 \\
\hline & 50 & 10 & 0.36 & 8.13 & 124 & 3.0 & 108 \\
\hline & 50 & 15 & 1.29 & 7.54 & 121 & 3.5 & 111 \\
\hline & 25 & 15 & 3.13 & 7.52 & 101 & 3.2 & 93 \\
\hline & 50 & 20 & 2.72 & 7.57 & 110 & 3.5 & 128 \\
\hline & 50 & 25 & 3.26 & 7.65 & 106 & 3.8 & 93 \\
\hline & 50 & 30 & 3.45 & 7.67 & 103 & 2.7 & 99 \\
\hline & 50 & 35 & 4.00 & 7.75 & 103 & 3.0 & 124 \\
\hline & 200 & 35 & 2.87 & 7.47 & 105 & 4.0 & 99 \\
\hline & 50 & 40 & 3.61 & 7.42 & 92 & 3.2 & 104 \\
\hline Carbaryl + & 900 & & 1.74 & 7.92 & 129 & 6.8 & 125 \\
\hline $\mathrm{NAA}+$ & 10 & & & & & & \\
\hline 70 -sec oil & 2500 & 15 & & & & & \\
\hline Ethephon & 1500 & 15 & 0.09 & 7.24 & 33 & 9.7 & 89 \\
\hline Defruited & & 15 & 0.24 & 8.31 & 123 & 8.0 & 155 \\
\hline Deblossomed & & 5 & 0.08 & $\cdots$ & 129 & 9.0 & 156 \\
\hline LSD $(P=0.05)$ & & & 0.88 & 0.37 & 18.25 & 2.4 & 45.05 \\
\hline
\end{tabular}

${ }^{\mathrm{z} X-77}$ at $0.0125 \%(\mathrm{v} / \mathrm{v})$ was added to terbacil treatments.

yAll spray treatments were applied with a hand-pump sprayer. Fruit size was $8.95 \pm 0.32 \mathrm{~mm}$ on 4 May (FB +15 days). ×Full bloom occurred 19 Apr. 1985.

wAverage shoot length for five terminals (four scaffolds plus central leader) was $49.4 \mathrm{~cm}$; trunk diameter increment was $0.765 \mathrm{~cm}$ for the controls.

'Return bloom was rated 17 Apr. 1986 at $25 \%$ bloom open $(0=$ no bloom; $5=$ enough for full crop; $10=$ all spurs flowering).

Table 4. Effect of length and time of shade on 'Redchief Delicious' fruit thinning and fruit size (Expt. 5, 1986).

\begin{tabular}{lcccccc}
\hline $\begin{array}{c}\text { Duration } \\
\text { of shade } \\
\text { (days) }\end{array}$ & $\begin{array}{c}\text { Timing } \\
(\mathrm{DAFB})\end{array}$ & $\begin{array}{c}\text { Fruit/cm } \\
\text { cross-sectional } \\
\text { area of trunk } \\
(\mathrm{FB}+61)\end{array}$ & $\begin{array}{c}\text { Fruit diameter } \\
(\mathrm{FB}+122) \\
(\mathrm{cm})\end{array}$ & $\begin{array}{c}\text { Average } \\
\text { shoot } \\
\text { length }\end{array}$ & $\begin{array}{c}\text { Trunk diameter } \\
\text { increment } \\
\text { (\% of control) }\end{array}$ & $\begin{array}{c}1986 \\
\text { (\% of control) }\end{array}$ \\
\hline No shade & -- & & 5.15 & 6.68 & 100 & 100 \\
Shaded & 1 & $13-14$ & 4.31 & 6.78 & 106 & 107 \\
& 3 & $12-15$ & 2.86 & 7.32 & 98 & 136 \\
& 5 & $11-16$ & 1.92 & 7.52 & 109 & 163 \\
& 7 & $10-17$ & 1.97 & 7.52 & 106 & 135 \\
& 5 & $18-23$ & 0.70 & 7.52 & 124 & 178 \\
& 5 & $23-28$ & 0.27 & 7.80 & 97 & 185 \\
Hand-thinned & 5 & $28-33$ & 0.60 & 7.37 & 124 & 132 \\
LSD $(P=0.05)$ & 5 & $33-38$ & 1.41 & 7.11 & 94 & 33 \\
\hline
\end{tabular}

zFull bloom (FB) occurred 22 Apr. 1986. Fruit size was $8.2 \pm 0.4 \mathrm{~mm}(+14 \mathrm{DAFB}) ; 10.0 \pm 0.4 \mathrm{~mm}(+17$ DAFB); $15.2 \pm 0.9 \mathrm{~mm}$ (+24 DAFB); $24.0 \pm 0.8 \mathrm{~mm}$ (+33 DAFB); $30.0 \pm 0.6 \mathrm{~mm}(+38$ DAFB).

yAverage shoot length for five terminals (four scaffolds plus central leader) was $46.9 \mathrm{~cm}$; trunk diameter increment was $0.48 \mathrm{~cm}$.

for the defruited terbacil treatments was equivalent to the control, hand-thinned, deblossomed, and defruited trees. Fruit color, firmness, and SSC were not affected by shade or terbacil. Res- idue analysis of fruit from terbacil $\left(50 \mathrm{mg} \cdot \mathrm{liter}^{-1}\right)+\mathrm{X}-77$ trees showed non-detectable levels of terbacil in the fruit. The legal tolerance set by the U.S. Environmental Protection Agency is 


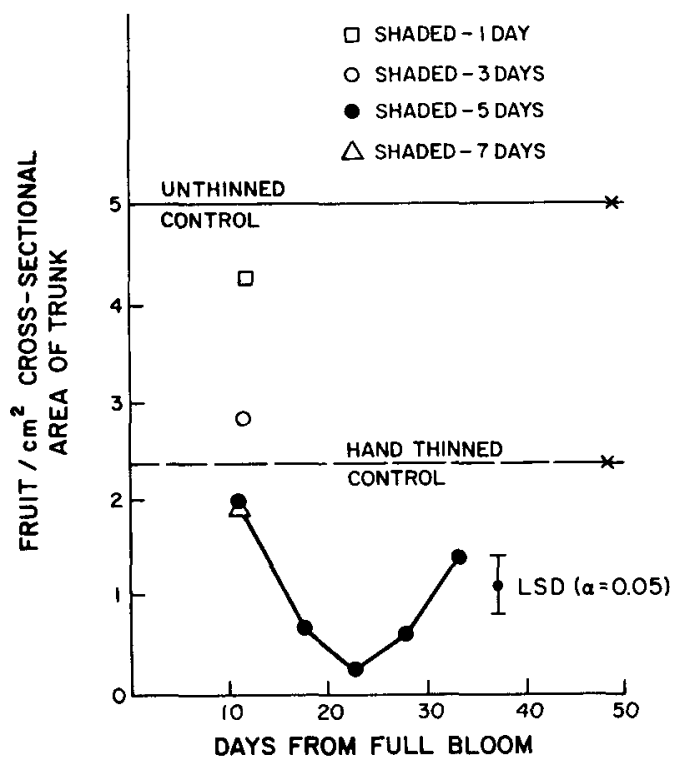

Fig.2. Effect of shading whole trees of 'Redchief Delicious' on fruit set. Each point represents fruit set on six shaded trees enclosed with 92\% shade material for the period indicated, hand-thinned, and unthinned controls. [The point was placed at the beginning date of each shade period (Expt. 5, 1986).] Vertical bar represents LSD, $P=$ 0.05 .

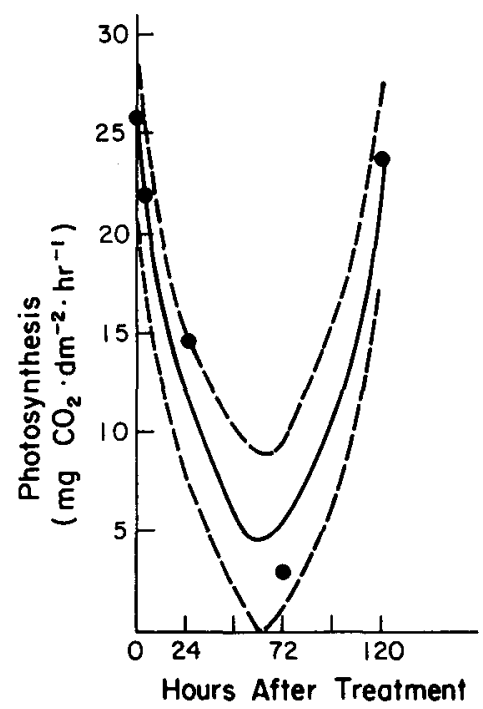

Fig. 3. Effect of terbacil on net photosynthesis of 'Redchief Delicious' trees sprayed at various times before measurement $(\mathrm{y}=24.9$ - 0.6.57x $\left.+0.005 \mathrm{x}^{2}\right)\left(R^{2}=0.899\right)($ Expt. 6, 1986). Dotted lines represent confidence limit belts, $P=0.05$.

currently $0.1 \mathrm{mg} \cdot \mathrm{g}^{-1}$ fresh weight for terbacil on fruit when used as a herbicide in apple orchards.

Experiment 5. In 1986, shading trees 12 to 15 DAFB for 3 days caused fruit thinning, even though the most and about equally sensitive periods to shade were 18 to 23,23 to 28 , and 28 to 33 DAFB (Fig. 2, Table 4). Fruit sizes on nonshaded trees in the 1986 experiments were $8.2 \pm 0.4 \mathrm{~mm}$ (14 DAFB); 10.0 $\pm 0.4 \mathrm{~mm}(17 \mathrm{DAFB}) ; 15.2 \pm 0.9 \mathrm{~mm}(24 \mathrm{DAFB}) ; 24.0 \pm$ $0.8 \mathrm{~mm}$ (33 DAFB); $30.0 \pm 0.6$ (38 DAFB); and $33.5 \pm 1.2$ $\mathrm{mm}$ (41 DAFB). These data are interesting because fruit at the normal thinning stage $(10 \mathrm{~mm}, 7 \mathrm{DAFB})$, as well as larger fruit (24 mm, 33 DAFB), were very sensitive to shade. Fruit size at harvest was inversely related to crop load (Table 4). Trees shaded for 5 days (28 to 33 and 33 to $38 \mathrm{DAFB}$ ) produced smaller fruit than trees shaded 11 to 16 DAFB, even though crop loads were similar or smaller. Differences in fruit size between control and hand-thinned treatments were not as great as might be expected, but trees were young and controls were not greatly over-cropped. Shoot length and trunk diameters were increased when trees were thinned most severely.

Experiment 6. Twenty days after full bloom, Pn of trees treated with terbacil $\left(50 \mathrm{mg} \cdot \mathrm{liter}^{-1}\right)+\mathrm{X}-77\left(1250 \mathrm{mg} \cdot \mathrm{liter}^{-1}\right) 72 \mathrm{hr}$ before measurement was reduced to $=10 \%$ of nontreated trees, but trees treated $120 \mathrm{hr}$ before measurement were photosynthesizing at near-normal levels (Fig. 3).

Experiment 7. Leaf Pn measured 20 DAFB on trees shaded 5 to 15 DAFB was less than the control, and some leaves showed obvious red pigmentation (Table 5). Shade removal after 10 days may have caused light-induced destruction of chlorophyll for the subsequent 5 days, possibly leading to the visible expression of redness of some leaves. Before shade removal, the Pn of trees shaded 10 to 20 DAFB was equal to that of trees shaded on the 20th DAFB, about one-third of the control. After removal, the Pn of trees shaded 10 to 20 DAFB was similar to that of the control.

\section{Discussion}

Fruit abscission caused by shading or terbacil treatment suggests a brief period after bloom when the fruits are extremely sensitive to the application of a photosynthetic inhibitor or a Imitation of light by shading. However, the sensitive period for shade-thinning apparently extends well-past the 10-mm-diameter stage of fruit development; i.e., past the period when fruit are most susceptible to "thinning by growth-regulator and carbamate chemical thinning agents.

All of the Pn inhibitors tested in these studies were originally selected for their persistence as herbicides. Other Pn inhibitors that are more short-lived may have potential as thinning agents, with less risk of over-thinning and leaf injury. Many of the persistent Pn inhibitors, such as terbacil, are normally used as root-absorbed herbicides and may not be appropriate for foliar application. Since all of the Pn inhibitors from the five classes tested were active as thinning agents, more-suitable thinning agents may be found among other Pn inhibitors.

Shading limbs of 20-year-old 'Starkrimson' trees in a previous study (Byers et al., 1985) indicated that fewer fruit abscised from shading 10 days (16 to 26 DAFB) than shading younger, whole trees of 'Redchief' in these experiments. When limbs in the previous studies (Byers et al., 1985) were shaded 26 to 36 DAFB, no thinning occurred, but whole trees were almost completely defruited when shaded 25 to 35 DAFB. These results suggest that shading whole trees was more effective than shading limbs on old trees. We believe limb experimental units were less-responsive to shading treatments than whole 'Redchief' trees and a significant compensatory effect is likely in limb experiments. However, the whole-tree shading experiment was on much younger trees than the limb-shading experiment (Byers et al., 1985). An additional experiment would be required to test the compensatory effect when single limbs are shaded.

Since photosynthetic inhibitors or short periods of shading can dramatically reduce set, we suspect that cloudy periods as short as 3 days, or even less, may greatly affect fruit set under natural conditions. The combined effect of a chemical thinner 
Table 5. Effect of shading and removal of shade material on photosynthesis of 'Redchief Delicious' apple leaves (Expt. 7, 1985). ${ }^{2}$

\begin{tabular}{|c|c|c|}
\hline Treatment ${ }^{y}$ & $\begin{array}{c}\text { Photosynthesis } \\
\left(\mathrm{mg} \mathrm{CO} / \mathrm{Cm}^{2} \text { per hr) }\right. \\
(\mathrm{FB}+20)\end{array}$ & Leaf color \\
\hline No shade & $26 a$ & Green \\
\hline $\begin{array}{l}\text { Shade FB }+5 \text { to }+15 \\
\text { (shade off } F B+15 \text { ) }\end{array}$ & $17 \mathrm{~b}$ & Red leaf pigments prominent \\
\hline $\begin{array}{l}\text { Shade FB }+10 \text { to } 20 \\
\text { (shade on FB }+20 \text { ) }\end{array}$ & $8 \mathrm{c}$ & Green \\
\hline $\begin{array}{l}\text { Shade FB }+10 \text { to }+20 \\
\text { (shade off FB }+20 \text { ) }\end{array}$ & $23 \mathrm{a}$ & Green \\
\hline $\begin{array}{l}\text { Shade FB }+20 \\
\text { (shade on FB }+20)\end{array}$ & $7 \mathrm{c}$ & Green \\
\hline
\end{tabular}

and environmental shading should be extensively investigated. Our measurements of photosynthetic photon flux (PPF) levels show that PPF at Winchester was reduced by $85 \%$ to $90 \%$ of full sun on a typical cloudy day, and during rainy days it was even less. An understanding of the interactions between cloudy weather, fruit set, chemical thinning application methods, and stage of fruit physiological development is critical for reproducible thinning results.

Apple fruit abscission after fertilization and during June drop is considered to result from the competition for essential metabolites among individual fruitlets, and between fruitlets and vegetative shoots (Abbott, 1960; Quinlan and Preston, 1971; Wardlaw, 1968). Schneider and Lasheen (1973) and Schneider $(1975,1977)$ showed that NAA thinning sprays decreased the amount of reducing sugars in young apple fruitlets. Weinbaum and Simons (1974) also showed reduced starch deposition in seed tissue; this reduction was correlated with impending seed abortion in NAA-treated apples. Apparently, the first effect of hormone thinners is a reduced level of photosynthate reaching the developing fruit. Second, the most sensitive period for NAAinduced abscission in apples is 10 to 20 DAFB. Our data show that chemical photosynthetic-inhibitor activity and natural June drop are initiated at about the same critical period as hormone spray-thinning. Shade-thinning appears to be effective for a longer period than terbacil, NAA, or carbaryl applications. The mechanism leading to June drop or NAA-, carbaryl-, or ethyleneinduced abscission may be the same as that caused by photosynthetic inhibition, but absorption of chemicals as leaves age may limit their effect later in the season.

\section{Literature Cited}

Abbott, D.L. 1960. The bourse shoot as a factor in growth of apple fruits. Ann. Applied Biol. 48:434-438.

Byers, R.E. 1978. Chemical thinning of 'Golden Delicious' and 'Starkrimson Delicious' with Sevin and Vydate. HortScience 13:59-61.

Byers, R. E., C.G. Lyons, Jr., and R.L. Horsburgh. 1982. Comparisons of Sevin and Vydate for thinning apples, HortScience 17:777778.
Byers, R. E., C.G. Lyons, Jr., T.B. DelValle, J.A. Barden, and R.W. Young. 1984. Peach fruit abscission by shading and photosynthetic inhibition. HortScience 19:649-51.

Byers, R. E., C.G. Lyons, Jr., K.S. Yoder, J,A. Barden, and R.W. Young. 1985. Peach and apple thinning by shading and photosynthetic inhibition. J. Hort. Sci. 60:465-472.

DelValle, T. B., J.A. Barden, and R.E. Byers. 1985. Thinning of peaches by temporary inhibition of photosynthesis with terbacil. J. Amer. Soc. Hort. Sci. 110:804-807.

Herrera-Aguirre, E. and C.R. Unrath. 1980. Chemical thinning response of 'Delicious' apples to volume of applied water. HortScience 15:43-44.

Pease, H. L., R.E. Leitch, and O.R. Hunt. 1978. Terbacil, p. 483492. In: G. Zweig (cd.). Analytical methods for pesticides and plant growth regulators. vol. 10. Academic, New York.

Quinlan, J.D. and A.P. Preston. 1971. The influence of shoot competition on fruit retention and cropping of apple trees. J. Hort. Sci. 46:525-534.

Rogers, B.L. and A.H. Thompson. 1969. Chemical thinning of apple trees using concentrate sprays. J. Amer. Soc. Hort. Sci. 94:23-24.

Rogers, B.L. and G.R. Williams. 1977. Chemical thinning of spurtype Delicious apple trees. Virginia Fruit 65:23-28.

SAS Institute, Inc., 1982. Users guide: Statistics 1982. SAS Institute, Raleigh, N.C.

Schneider, G.W. 1975. ${ }^{14} \mathrm{C}$-sucrose translocation in apple. J. Amer. Soc. Hort. Sci. 100:22-24.

Schneider, G.W. 1977. Studies on the mechanism of fruit abscission in apple and peach. J. Amer. Soc. Hort. Sci. 102: 178-181.

Schneider, G.W. and A.M. Lasheen. 1973. NAA and Sevin on composition, development and abscission of apple fruit. HortScience 8:103-104.

Unrath, C.R. 1978. The development of ethephon's thinning potential for spur 'Delicious' apples. Acts Hort. 80:233-243.

Unrath, C.R. 1981. An overview of environmental factors affecting orchard growth regulator response with special reference to apples. Acts Hort. 120:43-52.

Wardlaw, I.F. 1968. The control and pattern of movement of carbohydrates in plants. Bet. Rev. 34:79-105.

Weinbaum, S.A. and R.K. Simons. 1974. Histochemical appraisal of the relationship of seed abortion to chemical induction of apple fruit abscission following bloom. J. Amer. Soc. Hort. Sci. 99:266-269. 